\title{
Effect of Essential Fatty Acid Proportion in Feed on Productive and Reproductive Performance of Japanese Quail (Coturnix coturnix japonica)
}

\section{-Author(s)}

Castro-Tamayo CBI(D) https://orcid.org/0000-0002-5639-3371 Rios-Rincón FG' (D) https://orcid.org/0000-0001-6674-4318 Castillo-Lopez RI" (iD https://orcid.org/0000-0003-1494-7863 Contreras-Pérez G(iD) https://orcid.org/0000-0001-8388-0485 Molina-Barrios RM" (D) https://orcid.org/0000-0002-3285-5738 Heredia JB IV (D) https://orcid.org/0000-0003-1017-957X Muy-Rangel MDIViD https://orcid.org/0000-0002-6971-535X Portillo-Loera JJ' (iD https://orcid.org/0000-0002-5990-7841

Universidad Autonoma de Sinaloa - FMVZ Blvd. San Angel 3886 Fracc. San Benito, Culiacan, Sinaloa 80246 Mexico.

Facultad de Ciencias Químico Biologicas Blvd. de las Américas y Josefa Ortiz de Domínguez S/N. Ciudad Universitaria, Culiacan, Sinaloa 80013 Mexico.

III Ciencias Agronómicas y Veterinarias Antonio Caso 2266, Villa ITSON, Cd. Obregon, Sonora 85130 Mexico.

iv Centro de Investigación en Alimentación y Desarrollo, AC - Functional Foods and Nutraceuticals Carretera a El Dorado Km 5.5 Col. Campo el Diez, Culiacán, Sinaloa 80110 Mexico.

\section{Mail Address}

Corresponding author e-mail address Jesus Jose Portillo-Loera

Unidad Avicola, Facultad de Medicina Veterinaria y Zootecnia, Universidad Autonoma de Sinaloa Bivd. San Angel 3886 Fracc. San Benito, Culiacan, Sinaloa 80246 México.

Phone: +52 (667)7181650

Email: portillo6422@uas.edu.mx

\section{aKeywords}

Omega-3, n-6:n-3 ratio, linolenic acid, hatchability, embryonic mortality.

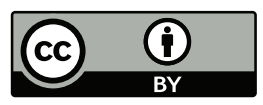

Submitted: 19/August/2019 Approved: 23/November/2019

\section{ABSTRACT}

This investigation was carried out to determine the effect of Essential Fatty Acids proportion (EFAs [n-6, n-3]) in feed through the mixture of soy, olive, canola or chia oil on EFA profile in eggs as well as productive and reproductive performance of Japanese quail. We used 120 quail from 7 to 22 weeks of age, in 15 cages in groups of 6 females and 2 males assigned according to the completely randomized design to 3 treatments with 5 replicates. The treatments were n-6:n-3 proportions 10:1 (control), 4:1 and 1:1. FA profile in yolk, feed intake, laying rate, egg weight, fertility, hatchability, and embryonic mortality were measured. In the egg yolk, n-6 content was similar in the proportions $(p>0.05)$, while $n-3$ content increased $(p<0.01)$ as $n-6: n-3$ ratio decreased in the feed. Feed consumption per quail was similar between treatments ( $p>0.05)$. In 4:1 and 1:1 proportion laying percentage was greater, but egg weight was lower $(p<0.01)$. Fertility and hatchability were similar between proportions $n-6, n-3(p>0.68)$. Early and total embryonic mortality was lower in $10: 1$ and $4: 1$ proportion $(p<0.01)$; while intermediate and late mortality was similar $(p>0.30)$. The results of the experiment indicate that the mixture of soy, olive, canola or chia oil, to obtain n-6:n-3 proportion of 1:1, 4:1 and 10:1 does not modify feed consumption, laying rate, egg weight, fertility, and hatchability; but, 4:1 and 10:1 proportions favor a lower embryonic mortality.

\section{INTRODUCTION}

During the incubation process in birds, egg yolk lipids are the energy reserves and provide the embryo the essential fatty acids (Cherian, 2015), necessary for the formation of cell membranes (Cherian et al., 1997). The polyunsaturated fatty acids (PUFA) linoleic acid (AL 18: $2 n-$ 6 ) and $\alpha$-linolenic acid (ALA; 18: $3 n-3$ ) are obtained by birds in feed. However, the ability to incorporate $n-3$ to the yolk can vary according to the source of PUFA and bird type: chicken, quail, turkey or geese (Nadia et al., 2012). Chickens have the liver enzymes delta-6-desaturase and delta-5-desaturase that allows them to synthesize from linolenic acid (n-3), eicosapentaenoic acid and docosahexaenoic acid (DHA) (BarcelóCoblijn \& Murphy, 2009), and from linoleic acid (n-6) arachidonic acid (AA) (Spector, 2000); however, n-6 and n-3 compete for liver enzymes in the biochemical pathways of desaturation and elongation (Jing et al., 2013). AA and DHA are important during the post-hatching period due to rapid cell proliferation and intense tissue accumulation of these during this time (Cherian \& Sim, 1992), as well as favoring the maturation of lymphoid organs (Cherian et al., 1997), therefore their function is likely important during incubation (Cherian \& Sim, 1992).

The Japanese quail (Coturnix coturnix japonica) is native to Europe, North Africa and Asia, (Neumann, 2001); it is of rapid growth, precocity, 
Castro-Tamayo CB, Rios-Rincón FG, Castillo-Lopez R, Contreras-Pérez G, Molina-Barrios R, Heredia JBI, MuyRangel MD, Portillo-Loera JJ
Effect of Essential Fatty Acid Proportion in Feed on Productive and Reproductive Performance of Japanese Quail (Coturnix coturnix japonica) resistance to diseases and high productivity (Lucotte, 1980). Quail meat production is concentrated in Spain, France, and the United States, and egg production in China, Japan and Brazil (Minvielle, 2004). Studies have been conducted in quails to enrich the egg with $n-3$ by including up to $4 \%$ fish oil or flaxseed in feed (Güçlü, 2008; Al-Daraji et al., 2010). However, the results of supplementation with sources containing $n-3$ showed no effect on fertility and hatchability of lightweight breeder hens (Nadia et al., 2012) or quails (Manohar, 2017); and even decreased in heavy reproductive hens (Herstad et al., 2000). There was increased fertility in turkey (Shamma et al., 2016) and quail hens (Manohar, 2017), as well as an increase in hatchability in quails (Al-Daraji et al., 2010; Manohar, 2017). AlDaraji et al. (2010) observed that quail fertility and hatchability improved by including 3\% fish or flaxseed oil compared to sunflower oil. It is possible to attribute this effect to the narrowest $n-6: n-3$ proportion in fish and flaxseed oil than in sunflower oil. However, in the studies conducted, the effect of the source of EFA was determined regardless of the $n-6: n-3$ proportion; therefore, the objective of this study was to determine the effect of $n-6: n-3$ proportion in the feed on EFA profile of the egg as well as productive and reproductive performance of Japanese quail.

\section{MATERIALS AND METHODS}

The experiment was carried out in the Poultry Unit of the Facultad de Medicina Veterinaria y Zootecnia of the Universidad Autonoma de Sinaloa, in Culiacan

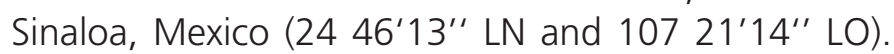
The climate of the zone is BS $\left(h^{\prime}\right) w(w)(e)$, semi-dry very hot, with rains in the summer, Köppen classification; with an annual average temperature of $25.9{ }^{\circ} \mathrm{C}$; average relative humidity of $68 \%$, maximum of $81 \%$ and minimum $51 \%$; average annual precipitation of $688.5 \mathrm{~mm}$.

The experiment was conducted according to the technical specifications for the production, care and use of laboratory animals of the Mexican official standard (NOM-062-ZOO-1999); and the specifications of the Institutional Committee for the Care and Use of Animals of the Facultad de Medicina Veterinaria y Zootecnia of the Universidad Autonoma de Sinaloa (Protocol FMVZ-171/11-11-2016). The experimental period comprised four periods of 21 days for productive response and nine periods of 24 days for reproductive response. Before initiating data collection, the quails were adapted to cage management for seven days.
120 quails (90 females and 30 males) were utilized. Egg collection was performed twice a day (08:00 a.m. and 18:00 p.m.). The temperature and relative humidity (RH) in the coop was $25.2 \pm 3.7^{\circ} \mathrm{C}$ and 40.7 $\pm 7.2 \%$, respectively.

The experiment was established under a completely randomized design with three treatments corresponding to diets with $n-6: n-3$ proportions in feed: (control) 10:1, 4:1 and 1:1, with five replicates of 8 quails ( 6 females and 2 males) per treatment, and weeks as a cross-factor. The wire battery cages $(60 \mathrm{x}$ $50 \times 20 \mathrm{~cm}$ ) allowed $375 \mathrm{~cm}^{2}$ per quail. The lighting period was $16 \mathrm{~h}$ per day and the feed and water were offered ad libitum.

To formulate the diets, fatty acid (FA) profile of soy, olive, canola or chia oil (Table 1); as well as proximal chemical composition (AOAC, 2000) of corn and soybean meal was determined. Metabolizable energy of corn and soybean meal was estimated with the equation: $\mathrm{MS}(\mathrm{kcal} / \mathrm{kg})=3.75 \times$ crude protein $+8.09 \times$ ether extract $-6.95 \times$ crude fiber $+3.94 \times$ nitrogen-free extract (Moir et al., 1980).

Table 1 - Fatty acids profile of oils included in the diet.

\begin{tabular}{lccc}
\hline \multicolumn{3}{c}{ Fatty acid $(\%)^{1}$} \\
\hline Oil & Linolenic & Linoleic & Oleic \\
\hline Soy & $5.63 \pm 0.71$ & $50.91 \pm 0.10$ & $31.67 \pm 0.99$ \\
Olive & $0.71 \pm 0.01$ & $5.01 \pm 0.03$ & $82.55 \pm 0.04$ \\
Canola & $13.62 \pm 3.88$ & $17.79 \pm 1.90$ & $46.19 \pm 2.10$ \\
Chia & $57.23 \pm 1.73$ & $19.88 \pm 0.37$ & $15.23 \pm 1.72$ \\
\hline
\end{tabular}

'Mean \pm standard deviation $(n=3)$.

The diets (Table 2) were formulated according to the nutritional requirements for Japanese quail breeders (NRC 1994), and the composition of EFA profile of every oil was considered. A flour-based feed was prepared every week and stored in plastic boxes at 20 to $22^{\circ} \mathrm{C}$, subsamples were taken from each batch of feed to determine FA (Table 3) and Proximate chemical analysis. The peroxide index in the feed (NMX-F-154-1987) was measured in the samples after 7 days of storage (Table 3 ).

Three weeks into the laying cycle, based on shape, size and egg color, collection and selection were initiated. The eggs to be incubated were kept at 11.0 $\pm 0.41^{\circ} \mathrm{C}$ (Nieto Refrigerator, Critotec CFX-8 Model, Guadalajara, Jalisco, Mexico). An automatic incubator (Huacuja, Model 1200, Guadalajara, Jalisco, Mexico) was used, and the eggs were maintained at $37.44 \pm$ $0.22^{\circ} \mathrm{C}$ and $74.04 \pm 2.08 \% \mathrm{RH}$ for 334 hours, then they were transferred to a hatchery, where the eggs spent 3 to 4 days at $37.5 \pm 0.4^{\circ} \mathrm{C}$ and $90.2 \pm 0.41 \%$ 
Castro-Tamayo CB, Rios-Rincón FG,

Castillo-Lopez R, Contreras-Pérez G,

Molina-Barrios R, Heredia JBI, Muy-

Rangel MD, Portillo-Loera JJ

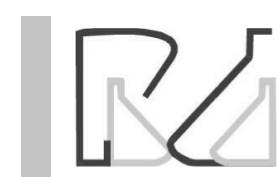

Table 2 - Composition and nutritional contribution of experimental diets.

\begin{tabular}{|c|c|c|c|}
\hline \multirow{2}{*}{ Ingredient (g/100 g) } & \multicolumn{3}{|c|}{ Proportion n-6:n-3 } \\
\hline & $10: 1^{2}$ & $4: 1$ & $1: 1$ \\
\hline Corn & 50.05 & 50.10 & 50.70 \\
\hline Soybean $46 \%$ & 35.90 & 36.10 & 35.70 \\
\hline Soybean oil & 3.45 & 2.65 & 0 \\
\hline Olive oil & 1.32 & 0 & 0 \\
\hline Canola oil & 0 & 1.20 & 0.90 \\
\hline Chia oil & 0 & 0.65 & 3.50 \\
\hline Salt & 0.25 & 0.25 & 0.25 \\
\hline L-lysine 78\% & 0.43 & 0.50 & 0.45 \\
\hline L-threonine 98\% & 0.35 & 0.35 & 0.35 \\
\hline DL-methionine $98 \%$ & 0.50 & 0.50 & 0.50 \\
\hline Limestone & 5.80 & 5.70 & 5.70 \\
\hline Dicalcium phosphate & 1.15 & 1.20 & 1.10 \\
\hline Vitamins and mineral premix $x^{1,3}$ & 0.25 & 0.25 & 0.25 \\
\hline Pigment $^{4}$ & 0.10 & 0.10 & 0.10 \\
\hline Probioticyeast (Saccharomyces cerevisiae) & 0.20 & 0.20 & 0.20 \\
\hline Adsorbent ${ }^{5}$ & 0.10 & 0.10 & 0.10 \\
\hline Phytase $^{6}$ & 0.20 & 0.20 & 0.20 \\
\hline \multicolumn{4}{|l|}{ Calculated composition } \\
\hline Crude protein (\%) & 20.28 & 20.03 & 20.00 \\
\hline Metabolizable energy (kcal/kg) & 3202 & 3149 & 3088 \\
\hline Lysine (\%) & 0.66 & 0.73 & 0.68 \\
\hline Methionine (\%) & 0.75 & 0.75 & 0.75 \\
\hline Cysteine (\%) & 0.33 & 0.33 & 0.33 \\
\hline Threonine (\%) & 1.11 & 1.11 & 1.11 \\
\hline Tryptophan (\%) & 0.30 & 0.30 & 0.29 \\
\hline Calcium (\%) & 2.53 & 2.51 & 2.52 \\
\hline Non-phytate phosphorous (\%) & 0.35 & 0.40 & 0.38 \\
\hline Crude fiber (\%) & 3.61 & 3.63 & 3.61 \\
\hline Ether extract (\%) & 6.96 & 6.63 & 6.61 \\
\hline Linoleic acid (\%) & 3.24 & 3.06 & 2.11 \\
\hline Dry matter (\%) & 89.85 & 90.15 & 90.19 \\
\hline \multicolumn{4}{|l|}{ Analyzed composition } \\
\hline Crude protein (\%) & 21.75 & 21.08 & 21.04 \\
\hline Ether extract (\%) & 6.31 & 5.87 & 4.40 \\
\hline Ash (\%) & 9.77 & 9.21 & 10.25 \\
\hline Moisture (\%) & 10.02 & 8.40 & 8.61 \\
\hline Crude fiber (\%) & 1.99 & 2.25 & 1.52 \\
\hline
\end{tabular}

${ }^{1}$ Composition of vitamin premix per kg: 12,500 IU (retinol); 4,480 IU (cholecalciferol); 30 IU (tocopherol acetate); 3 mg Menadione sodium bisulfide; $1.5 \mathrm{mg}$ thiamin; $6 \mathrm{mg}$ riboflavin; $3 \mathrm{mg}$ pyridoxine; $15 \mathrm{mg}$ cyanocobalamin; $1.5 \mathrm{mg}$ folic acid; $55 \mathrm{mg}$ niacin; 15 mg Ca pantothenate; $180 \mu$ g biotin; 600 mg choline; 120 mg Banox (BHA + BHT).

${ }^{2}$ Control treatment.

${ }^{3}$ Composition of mineral premix per kg: 75 mg Mn; 75 mg Zn; 75 mg Fe; 900 mg Mo; $750 \mu \mathrm{g} \mathrm{Co} ; 05$ mg Se.

${ }^{4}$ Florafil HP, Industrias Vepinsa, S.A. de C.V.

${ }^{5}$ Aluminosilicate, Zeolex.

${ }^{6}$ Natuphos* 5000 GP Fitasa, Basf Mexicana, S.A. de C.V.
Effect of Essential Fatty Acid Proportion in Feed on Productive and Reproductive Performance of Japanese Quail (Coturnix coturnix japonica)

$\mathrm{RH}$. Withdrawal of chicks began around $12 \mathrm{~h}$ after hatching began. The unhatched eggs were broken and observed with the naked eye to determine if they were fertile, as well as the stage of embryonic death; and classified as early, intermediate, late and total embryonic death according to the classification proposed by Dalton, (2000). At week 20 of the laying cycle, three eggs from every treatment were randomly collected for FA determination.

Fatty acid profile of feed yolk and oils was carried out at the Food Technology Laboratory in the Research Center for Food Development Food in Culiacan Sinaloa utilizing the methods developed by Folch et al. (1957) and AOAC (1998) standard 963.22 with modifications; subsequently they were dry evaporated in a rotary evaporator, after methylation the filtrate was recovered in a $2 \mathrm{~mL}$ vial, stored in a nitrogen atmosphere and placed in the freezer. Subsequently, $1 \mu \mathrm{L}$ of the sample was injected into a gas chromatograph. The methyl esters dissolved in hexane were analyzed with a chromatograph (Varian CP-3800, USA), with flame ionization detector (FID) equipped with Omegawax 320 column of $30 \mathrm{~m} \times 0.32 \mathrm{~mm}, 0.25 \mathrm{~mm}$ internal diameter (Supelco, USA). Helium was used as a carrier gas at a rate of $3 \mathrm{~mL} / \mathrm{min}$. The oven temperature was maintained at $140^{\circ} \mathrm{C}$ for 5 minutes, presetat a maximum temperature of $240^{\circ} \mathrm{C}$ with an increase of $4^{\circ} \mathrm{C}$ every 90 seconds. Both the temperature of the injector and the detector were set at $260^{\circ} \mathrm{C}$. For the identification and quantification of fatty acids, the retention time of sample was compared with those of a standard mixture consisting of 37 methyl esters of fatty acids (Supelco, Bellefonte, USA).

FA results were expressed in percentage of fatty acid with respect to the percentage of fat contained in the sample. The peroxide value was expressed in meq $\mathrm{O}_{2} / \mathrm{kg}$. In productive response, after every feed consumption period, egg number and weight were recorded. For reproductive response after every egg collection, fertility rate, hatchability of fertile eggs and early, intermediate, late and total mortality were recorded.

The statistical analysis of FA results in egg yolk, feed intake, laying percentage, egg weight, fertility and hatchability were performed under a model for a completely randomized experimental design. The comparison of means was made with the Tukey test. The proportions of embryonic mortality were analyzed with the Chi-square test. The maximum alpha level to accept statistical difference was 0.05. 
Castro-Tamayo CB, Rios-Rincón FG, Castillo-Lopez R, Contreras-Pérez G, Molina-Barrios R, Heredia JBI, MuyRangel MD, Portillo-Loera JJ
Effect of Essential Fatty Acid Proportion in Feed on Productive and Reproductive Performance of Japanese Quail (Coturnix coturnix japonica)

Table 3 - EFA composition and contribution of $n-6: n-3$ as well as in dexperoxide index of quail diet.

\begin{tabular}{|c|c|c|c|c|c|c|}
\hline \multirow[b]{2}{*}{ Fatty acids $(\%)^{1}$} & \multirow[b]{2}{*}{ Nomenclature } & \multicolumn{3}{|c|}{ Proportion n-6:n-3 } & \multirow[b]{2}{*}{$\mathrm{SEM}^{3}$} & \multirow[b]{2}{*}{$p$-value } \\
\hline & & $10: 1^{2}$ & $4: 1$ & $1: 1$ & & \\
\hline Palmitic & C16:0 & $12.97^{\mathrm{a}}$ & $11.73^{\mathrm{ab}}$ & $10.76^{b}$ & 0.33 & 0.0095 \\
\hline Oleic & C18:1, cis-n-9 & $35.65^{\mathrm{a}}$ & $30.55^{b}$ & $23.52^{c}$ & 0.83 & 0.0001 \\
\hline Linoleic & C18:2, cis-9,12n-6 & $46.05^{a}$ & $46.18^{a}$ & $34.59^{b}$ & 0.42 & 0.0001 \\
\hline Linolenic & C18:3, cis-9,12,15n-3 & $4.78^{c}$ & $10.93^{b}$ & $30.57^{a}$ & 0.19 & 0.0001 \\
\hline Arachidic & $\mathrm{C} 20: 0$ & 0.543 & 0.613 & 0.560 & 0.04 & 0.4905 \\
\hline Saturated fatty acids (SFA) & & $12.97^{\mathrm{a}}$ & $11.73^{\mathrm{ab}}$ & $10.75^{b}$ & 0.33 & 0.0095 \\
\hline Monounsaturated fatty acids (MFA) & & $35.65^{a}$ & $30.54^{b}$ & $23.52^{c}$ & 0.83 & 0.0001 \\
\hline Polyunsaturated fatty acids (PFA) & & $51.37^{c}$ & $57.72^{b}$ & $65.72^{\mathrm{a}}$ & 0.56 & 0.0001 \\
\hline SFA/PFA & & $0.252^{\mathrm{a}}$ & $0.203^{b}$ & $0.163^{c}$ & 0.004 & 0.0001 \\
\hline$n-6$ & & $46.17^{\mathrm{a}}$ & $46.07^{\mathrm{a}}$ & $34.59^{b}$ & 0.40 & 0.0001 \\
\hline$n-3$ & & $4.78^{c}$ & $10.93^{b}$ & $30.57^{a}$ & 0.19 & 0.0001 \\
\hline$n-6: n-3$ & & $9.79^{a}$ & $4.28^{b}$ & $1.14^{c}$ & 0.26 & 0.0001 \\
\hline Peroxide index, $\mathrm{mEqO}_{2} / \mathrm{kg}$ & & $2.01^{\mathrm{b}}$ & $1.06^{c}$ & $4.79^{a}$ & 0.51 & 0.0001 \\
\hline
\end{tabular}

$a, b, c$ ifferent letters in row indicate statistical difference $(p<0.05)$.

${ }^{1}$ As of total lipids (\%).

${ }^{2}$ Control treatment.

${ }^{3}$ Standard error of the mean $(n=3)$.

\section{RESULTS AND DISCUSSION}

\section{Fatty acids in the yolk}

FA composition in egg yolk is shown in Table 4. According to the FA group, monounsaturated FA were found to be in the highest percentage, close to $50 \%$, due to its content of oleic and palmitoleic acids, followed by saturated FA that were present in about $30 \%$ and finally polyunsaturated FA at $20 \%$. Saturated FA were in greater percentage $(p<0.01)$ in the $4: 1$ $\mathrm{n}-6: \mathrm{n}-3$ proportion than in $10: 1$ and $1: 1$ proportions; where as myristic acid and stearic acid were detected in a similar reduced proportion between treatments; while erucic acid appeared in a greater percentage $(p<0.03)$ in the $1: 1$ proportion. Monounsaturated FA content was similar $(p>0.05)$; However, oleic and palmitoleic acids were in a greater percentage, nonetheless palmitoleic acid percentage was greater $(p<0.02)$ in the $4: 1$ proportion than in the $10: 1$ and $1: 1$ proportion. Polyunsaturated FA content was similar, although the 1:1 proportion had a higher content and was close to having a statistical difference $(p>0.08)$. Linoleic acid content had the greatest percentage and was similar between proportions $(p>0.05)$. Linolenic and docosadienoic acids were in greater percentage $(p<0.02)$ in the $1: 1$ proportion, which revealed a greater percentage of $n-3$ fatty acids $(p<0.01)$, in accordance to feed proportion and n-6:n-3 proportion also differed. Chen \& Hsu (2003) supplemented 2 to $6 \%$ refined cod liver oil to duck hens and observed that yolk concentration of saturated fatty acids decreased and while polyunsaturated fatty acids eicosapentaenoic (EPA) and docosahexaenoic (DHA) increased, compared to animal fat controls. In this study the $n-6: n-3$ proportion in feed remained in the egg yolk. Based on the amount of n-6 and n-3 fatty acids reported by Neijat et al. (2016) in egg yolk and chicken feed after the inclusion of hemp seed or oil as a source of $n-3$ it can be deduced that $n-6: n-3$ proportions in the diets is kept constant from 1.1 to 1.5 from feed to the egg yolk; this coincides with the results of Navas et al. (2001) in bass eggs (Dicentrarchus labrax L) where there was constant of 1.2 to 1.7 from feed to the egg yolk. In addition, arachidonic acid and eicosadienoic acid were detected in the yolk and were not detected in feed analysis; this is explained by the bird's ability to lengthen fatty acid chains (Spector, 2000; BarcelóCoblijn \& Murphy, 2009). It has been observed that lineages or strains can modify EFA profiles, (Mao et al., 1998). Alessandri et al. (2012) reported that slow-growing egg-type lines of chickens or layers appear to have greater efficiency in the deposition of EPA and DHA with respect to meat-type chickens since elongation is affected in part by estrogen levels. Arantes da Silva et al. (2009) after the inclusion of 5\% flax seed to quail diets reported that $n-3$ incorporation into the yolk was $20 \%$. Mennicken et al. (2005) made a divergent selection in chickens for $n-3$ : $n-6$ proportions and mentioned that $n-3$ increased $34.7 \%$ in the yolk with respect to feed content. These differences in the ability of these birds to incorporate $n-3$ to yolk fat can vary according to $\mathrm{n}-3$ source and bird species (Nadia et al., 2012), due to the competition between the enzymes involved in lengthening and desaturation of linoleic and linolenic acid. A 4:1 proportion or lower has been shown to be optimal for elongating $11 \mathrm{~g}$ of 
Castro-Tamayo CB, Rios-Rincón FG, Castillo-Lopez R, Contreras-Pérez G, Molina-Barrios R, Heredia JBI, MuyRangel MD, Portillo-Loera JJ

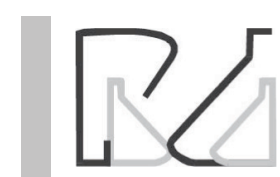

Effect of Essential Fatty Acid Proportion in Feed on Productive and Reproductive Performance of Japanese Quail (Coturnix coturnix japonica)

Table 4 - Fatty acid profile and n-6:n-3 proportions in quail egg olk.

\begin{tabular}{|c|c|c|c|c|c|c|}
\hline \multirow{2}{*}{ Fatty acids $(\%)^{1}$} & \multirow{2}{*}{ Nomenclature } & \multicolumn{3}{|c|}{ Proportion n-6:n-3 } & \multirow{2}{*}{$\mathrm{SEM}^{3}$} & \multirow{2}{*}{$p$-value } \\
\hline & & $10: 1^{2}$ & $4: 1$ & $1: 1$ & & \\
\hline Myristic & C14:0 & 0.34 & 0.46 & 0.33 & 0.046 & 0.160 \\
\hline Myristoleic & C14:1 & $0.03^{b}$ & $0.09^{a}$ & $0.05^{b}$ & 0.005 & 0.0008 \\
\hline Palmitoleic & C16:1, cis-9 & $27.32^{b}$ & $31.25^{\mathrm{a}}$ & $27.93^{b}$ & 0.717 & 0.017 \\
\hline Stearic & C18:0 & 0.26 & 0.20 & 0.21 & 0.024 & 0.248 \\
\hline Oleic & C18:1, cis-n-9 & 49.02 & 49.55 & 47.56 & 0.965 & 0.382 \\
\hline Linoleic & C 18:2 , cis-9,12n-6 & 15.85 & 13.46 & 12.78 & 1.079 & 0.189 \\
\hline Gamma-Linoleic & C $18: 3 n-6$ & ND & ND & 0.08 & ----- & ----- \\
\hline Linolenic & C18:3, cis-9,12,15n-3 & $0.43^{b}$ & $0.97^{b}$ & $3.14^{a}$ & 0.381 & 0.005 \\
\hline Eicosadienoic & C20:2, cis- $11,4 n-9$ & 0.77 & 2.14 & 2.01 & 0.429 & 0.119 \\
\hline Arachidonic & $C 20: 4 n-9$ & 0.12 & ND & 0.14 & ----- & 0.498 \\
\hline Behenic & $\mathrm{C} 22: 0$ & 3.01 & ND & ND & ----- & ----- \\
\hline Timnodonic or Eicosapentaenoic & C20:5, cis-5,8n-3 & ND & ND & 0.56 & ----- & ----- \\
\hline Erucic & $\mathrm{C} 21: 0$ & $0.29^{b}$ & $0.29^{b}$ & $0.62^{a}$ & 0.070 & 0.026 \\
\hline Docosadienoic & C22:2, cis- $13,16 n-6$ & $2.57^{\mathrm{ab}}$ & $1.61^{b}$ & $4.61^{\mathrm{a}}$ & 0.533 & 0.019 \\
\hline Saturated fatty acids (SFA) & & $27.92^{b}$ & $31.90^{\mathrm{a}}$ & $28.47^{b}$ & 0.743 & 0.018 \\
\hline Monounsaturated fatty acids (MFA) & & 50.22 & 52.06 & 50.37 & 1.247 & 0.546 \\
\hline Polyunsaturated fatty acids (PFA) & & 18.84 & 16.04 & 21.16 & 1.275 & 0.077 \\
\hline SFA/PFA & & 1.52 & 2.02 & 1.35 & 0.161 & 0.058 \\
\hline$n-6$ & & 18.42 & 15.07 & 17.39 & 1.240 & 0.228 \\
\hline$n-3$ & & $0.43^{c}$ & $0.97^{b}$ & $3.70^{a}$ & 0.380 & 0.002 \\
\hline$n-6: n-3$ & & $43.86^{a}$ & $16.96^{b}$ & $4.89^{c}$ & 2.451 & 0.0001 \\
\hline
\end{tabular}

$a, b, c$ Different letters in row indicate statistical difference $(p<0.05)$.

${ }^{1}$ As $\%$ of total lipid.

${ }^{2}$ Control treatment.

${ }^{3}$ Values are expressed as means \pm pooled standard error $(n=3)$.

$\mathrm{ND}=$ Not determined.

linolenic acid to $1 \mathrm{~g}$ of eicosapentaenoic acid (Nadia et al., 2012), this relationship is important in foods that have a higher linoleic acid content and lower linolenic acid content, since it will reduce the conversion to EPA which is biologically more active than linoleic acid. Therefore, the optimal intake of linoleic in relation to linolenic is crucial for normal metabolism (Simopoulos, 2000), which may be related to FA source, linseed and chia contain more LAN and algae and fish oils are a source of EPA, DHA that are not present in land-based plant or animal sources.

\section{Productive response}

The results for productive response are presented in Table 5. Quail feed consumption was similar between treatments $(p>0.05)$. These results coincide with the results observed by Morales-Barrera et al. (2013) who included 3\% tuna oil (Thunnus albacares) as a source of $\mathrm{n}-3$ in White Leghorn chicken diets, and with Baucells et al. (2000) who replaced fish oil with linseed oil or grape oil and tallow. Rodriguez-Michel et al. (2018) observed that after fish oil inclusion feed consumption decreased. A decrease in feed consumption when adding fish oil is related to a reduction in palatability (Hulan et al., 1989), although this may not happen as indicated by the results of Baucells et al. (2000). The inclusion of essential fatty acids sources of plant origin such as oils or seeds, may not affect feed palatability; Regarding this Al-Daraji et al. (2010) included 3\% sunflower, flax or corn oils in quail feed where n-6:n-3 proportion ranged from 0.08:1 to $251: 1$ and recorded a similar feed intake.

Table 5 - Effect n-6:n-3 proportion on productive performance of quail.

\begin{tabular}{|c|c|c|c|}
\hline Proportion & $\mathrm{FI}\left(\mathrm{g} \mathrm{d}^{-1}\right)$ & LR (\%) & HEW (g) \\
\hline $10: 1^{1}$ & 32.94 & $87.90^{b}$ & $14.15^{\mathrm{a}}$ \\
\hline $4: 1$ & 30.78 & $90.96^{a}$ & $13.63^{b}$ \\
\hline $1: 1$ & 30.59 & $91.28^{a}$ & $13.63^{b}$ \\
\hline $\mathrm{EEM}^{2}$ & 3.42 & 0.71 & 0.06 \\
\hline$p$-value & 0.33 & 0.01 & 0.01 \\
\hline \multicolumn{4}{|c|}{ a,b,cDifferent letters in column indicate statistical difference $(p<0.05)$. } \\
\hline \multicolumn{4}{|c|}{$\mathrm{Fl}=$ Feed intake, LR= Laying rate, $\mathrm{HEW}=$ Hatching ability egg weight. } \\
\hline \multicolumn{4}{|c|}{ 'Control treatment. } \\
\hline \multicolumn{4}{|c|}{${ }^{2}$ Standard error ofthe mean $(n=9)$. } \\
\hline
\end{tabular}

Quails fed 4:1 and 1:1 proportion had a higher laying rate than the $10: 1$ proportion $(p<0.01)$. The results obtained in other experiments are not consistent 
Castro-Tamayo CB, Rios-Rincón FG, Castillo-Lopez R, Contreras-Pérez G, Molina-Barrios R, Heredia JBI, MuyRangel MD, Portillo-Loera JJ
Effect of Essential Fatty Acid Proportion in Feed on Productive and Reproductive Performance of Japanese Quail (Coturnix coturnix japonica) and do not give a definite response, since Baucells et al. (2000) reported that laying rate was similar after the inclusion of fish, flaxseed, and grape oils as well as tallow, where PUFA $n-6: n-3$ proportions ranged from 1 to 38 in chicken feed, on the other hand, Betancourt \& Díaz (2009) reported that in broader proportions $(7: 1)$ laying rate was greater than in the narrowest proportion (2:1), $93.1 \%$ and $86 \%$, respectively.

In $4: 1$ and $1: 1$ proportion egg weight was lower $(p<0.01)$ with respect to the 10:1 proportion. These results are in agreement with those of Güclü et al. (2008) who added 4\% sunflower, corn, fish, soy, sesame, olive, cotton or walnut oils to quail feed and obtained eggs with a greater weight $(12 \mathrm{~g})$ in the n6:n3 200:1 proportion, compared with the 53:1 and $7: 1$ proportions of sunflower, corn or soybean oil which weighed 11.5 and $11.3 \mathrm{~g}$, respectively. The greater weight seen in the 10:1 ratio is explained by the lower laying rate (87\%) since there is a genetic and phenotypic negative correlation between these two parameters; in this respect, Hagger (1994) estimated a negative genetic correlation in hens (-0.267).

\section{Reproductive response}

Results in reproductive response are shown in Table 6. In this study, fertility was similar between treatments $(p>0.680)$. In studies where different sources containing EFA are supplemented, discrepancies on the effect on fertility are reported. Nadia et al. (2012) used $1.73 \%$ flaxseed oil in light reproductive hens, and Manohar (2017) included 4\% fish oil in quails and did not find any difference. In turkeys Fertility increased by $5.39 \%$ when $2 \%$ fish oil was supplemented and by $3.43 \%$ when $2 \%$ flaxseed oil was added (Shamma et al., 2016), fertility also increased by $12.75 \%$ after the inclusion of $2 \%$ fish oil in quail diets (Manohar, 2017), however Herstad et al. (2000) with diets that had $3 \%$ recycled vegetable oil or no oil at all observed that in diets for heavy reproductive hens with $n-6: n-3$ proportions of $1.03: 1$ to $1.12: 1$ with $3 \%$ fish oil fertility rate decreased (76.3 to $83.7 \%$ ) compared to $7.6: 1$ to $8.31: 1$ proportion (89.5 to $92.1 \%$ ). The source, quantity and lipid type in the diets are important. Bleisbois et al. (1997) mentions changes in the proportions of $n-6: n-3$ or phospholipid ratios affect sperm membrane structure and fluidity; this can alter fertility by modifying viability and ability of the sperm to interact with the reproductive tract of the female and thereby the union of the sperm with the ovum (Bongalhardo et al., 2009).

Hatchability of fertile eggs was similar between the treatments ( $p>0.95$ ). Discrepancies were also found on the effect of EFA supplementation on hatchability in the studies. Nadia et al. (2012) after the inclusion of 1.73\% of flax seed oil and $n-6: n-3$ proportions that varied from 2:1 to 10:1 in lightweight reproductive hens; and Manohar (2017) in quails with 2\% flaxseed, $4 \%$ fish and $2 \%$ and $4 \%$ linseed and fish oil combinations, did not observe differences in hatchability. Hatchability increased $3.2 \%$ and $6.17 \%$ when flaxseed or fish oil with $n-6: n-3$ proportions of $0.22: 1$ and $0.08: 1$ were supplemented in quails, compared to corn oil (42:1) (Al-Darji et al., 2010); Manohar (2017) supplemented quail diets with $2 \%$ fish oil and observed $5.4 \%$ greater hatchability compared to a zero oil control. On the other hand, Herstad et al. (2000) observed that in heavy reproductive hens, diets with $n-6: n-3$ proportions of $1.03: 1$ to $1.12: 1$ from $3 \%$ fish oil, hatchability decreased (73.2 to $77.5 \%$ ) compared to $7.55: 1$ to $8.31: 1$ proportion (88.5 to $92.4 \%$ ) obtained from diets with $3 \%$ of recycled vegetable oil or zero oil.

The $n-6: n-3$ proportion 1:1 had higher early and total embryo mortality $(p<0.01)$, while $10: 1$ and $4: 1$ proportions were similar ( $p>0.05$ ) (Figure 1). Al-Daraji et al. (2010) observed that in quails supplemented with 3\% fish oil total embryonic mortality was $2.92 \%$ compared to $12.32 \%$ with $3 \%$ sunflower oil inclusion. After supplementation with fish oil n-6:n-3 proportion was narrow (0.08:1) with respect to that of sunflower oil (251:1). When EFA content is higher and more double bonds exist, greater oxidation is possible. In this study, the peroxide index in feed a week after being prepared was $4.79 \mathrm{mEqO} / \mathrm{kg}$ in the $\mathrm{n}-6: \mathrm{n}-3$ 1:1

Table 6 - Effect of n-6:n-3 proportion in diets in fertility and hatchability fertile eggs.

\begin{tabular}{lccccc}
\hline Proportion & Transferred eggs & Fertile eggs & Chickens born & Fertility (\%) & Hatchability fertile eggs (\%) \\
\hline $10: 1^{1}$ & 1191 & 1154 & 943 & 95.13 & 83.56 \\
$4: 1$ & 1265 & 1210 & 999 & 94.50 & 83.87 \\
$1: 1$ & 1293 & 1235 & 920 & 94.24 & 84.18 \\
SEM $^{2}$ & & & & 0.74 & 1.44 \\
$p$-value Fisher & & & 0.680 & 0.950 \\
\hline
\end{tabular}

${ }^{1}$ Control treatment.

${ }^{2}$ Values are expressed as means \pm pooled standard error, $(n=9)$. 
Castro-Tamayo CB, Rios-Rincón FG, Castillo-Lopez R, Contreras-Pérez G, Molina-Barrios R, Heredia JBI, MuyRangel MD, Portillo-Loera JJ

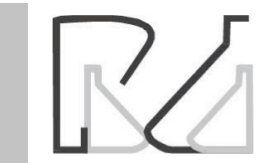

Effect of Essential Fatty Acid Proportion in Feed on Productive and Reproductive Performance of Japanese Quail (Coturnix coturnix japonica) proportion while in the $10: 1$ proportion a $2.01 \mathrm{mEqO}_{2} /$ $\mathrm{kg}(p<0.01)$ was recorded. Calder (2002) mentions that a greater proportion of $\mathrm{n}-3$ consumption can diminish immune response due to a susceptibility to oxidation due to its unsaturation. In this study, the highest mortality in the $1: 1$ proportion can be attributed to greater peroxidation of linolenic acid, in addition to the possibility of peroxidation of its products. Zanini et al. (2003) observed that when the n-6:n-3 proportion in their diet was narrow because it contained $32.3 \%$ linolenic acid, fertility in cockerels decreased, however, after vitamin E was administered, fertility increased.

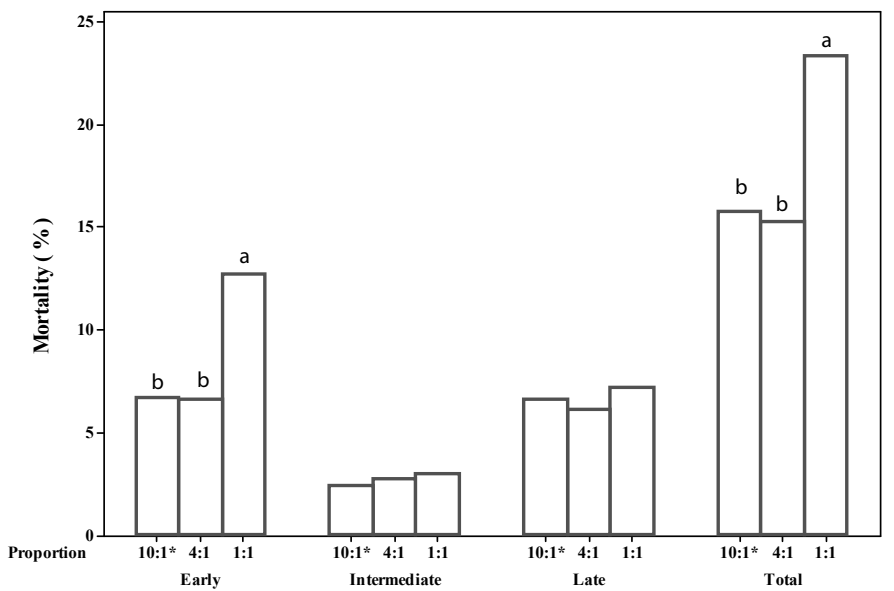

Figure 1 - Effect of n-6:n-3 proportion of in diets in embryo diagnosis an non eclosionated quail egg. abSignificant at $p \leq 0.01$ with chi square test. ${ }^{*}$ Control treatment.

\section{CONCLUSION}

The results of the experiment indicate that the mixture of soy, olive, canola or chia oil, to obtain n-6:n-3 proportions of $1: 1,4: 1$ and $10: 1$ does not modify feed consumption, laying rate, egg weight, fertility or hatchability; but, 4:1 and 10:1 proportion favor a diminished embryonic mortality.

Favoring breeder bird feeds that have $n-6$ and $n-3$ proportions close to $1: 1$ is relative; as shown by the results of this experiment which concludes that reproduction did not improve, therefore it is recommended that $n-6$ and $n-3$ content be taken into account and estimate feed consumption in milligrams or daily ingested feed percentage, more than proportion contained in diet.

\section{ACKNOWLEDGEMENTS}

We gratefully acknowledge to Laboratory of Antioxidants and Functional Foods. Centro de Investigación en Alimentación y Desarrollo, AC, forallowing the use of the Chromatography equipment for the fatty acid profile. The authors would also like to thank CONACYT-México for the scholarship granted.

\section{REFERENCES}

Al-Daraji HJ, Al-Mashadani HA, Al-Hayani WK, Al-Hassani AS, Mirza HA, Al-Hassani, AS. Effect of dietary supplementation with different oils on productive and reproductive performance of quail. Internacional Journal of Poultry Science 2010;9:429-435.

Alessandri JM, Extier A, Al-Gubory KH, Harbeby E, Lallemand M, Linard A, et al. Influence of gender on DHA synthesis: The response of rat liver to low dietary $\alpha$-linolenic acid evidence shigher $\omega 3 \Delta 4$-desaturation index in females. European Journal of Nutrition 2012;51(2):199-209.

AOAC. Official methods of analysis. $16^{\text {th }}$ ed. Washington; Association of Official Analytical Chemists; 1998.

AOAC. Official methods of analysis. 17th ed. Washington: Association of Official Analytical Chemists; 2000.

Arantes da Silva W, Naiverti Elias AH, Aricetti JA, Sakamoto MI, Murakami AE, Marques Gomes ST, et al. Quail egg yolk (Coturnix coturnix japonica) enriched with omega-3 fatty acids. Food Science and Technology 2009;42(2):660-663.

Barceló-Coblijn G, Murphy EJ. Alpha-linolenic acid and its conversion to longer chain n-3 fatty acids: benefits for human health and a role in maintaining tissue n-3 fatty acid levels. Progress Lipid Research 2009;48(6):355-74

Baucells MD, Crespo N, Barroeta AC, Lopez-Ferrer S, Grashorn MA. Incorporation of different polyunsaturated fatty acids in to eggs. Poultry Science 2000;79(1):51-59.

Betancourt L, Díaz G. Enriquecimiento de huevos con ácidos grasos omega-3 mediante la suplementación con semilla de Lino (Linum usitatissimum) en la dieta. Revista MVZ Córdoba 2009;14(1):1602-1610.

Blesbois E, Lessire M, Grasseau I, Hallouis JM, Hermier D. Effect of dietary fat on the fatty acid composition and fertilizing ability of fowl semen. Biology Reproduction 1997:56:1216-1220.

Bongalhardo DC, Leeson S, Buhr MM. Dietary lipids differentially affect membranes from different areas of rooster sperm. Poultry Science 2009;88:1060-1069.

Calder PC. Dietary modification of inflammation with lipids. Proceedings of the Nutrition Society 2002;61:345-358.

Chen TF, Hsu JC. Incorporation of n-3 long-chain polyunsaturated fatty acids in to duck eggy olks. Asian-Australasian Journal Animal Science 2003; 16:565-9.

Cherian G, Gopalakrishnan N, Akiba Y, Sim JS. Effectof maternal dietary n-3 fatty acids on the accretion of long-chain polyunsaturated fatty acids in the tissues of developing chick embryo. Biology of the Neonate 1997:72(3):165-174.

Cherian G, Sim JS. Preferential accumulation of n-3 fatty acids in the brain of chicks from eggs enriched with $\mathrm{n}-3$ fatty acids. Poultry Science 1992:71:1658-1668.

Cherian G. Nutrition and metabolism in poultry: role of lipids in early diet. Journa of Animal Science and Biotechnology 2015;6(1):28-33.

Dalton MN. Effects of dietary fats on reproductive performance, egg quality, fatty acid composition of tissue and yolk and prostaglandin levels of embryonic tissues in Japanese quail (Coturnix coturnix japonica) [thesis]. Blacksburg (USA): Virginia Polytechnic Institute; 2000.

Folch J, Lees M, Sloane-Stanley GH. A simple method for isolation and purification of total lipids from animal tissues. Journal of Biological Chemistry 1957;226(1):497-509. 
Castro-Tamayo CB, Rios-Rincón FG, Castillo-Lopez R, Contreras-Pérez G, Molina-Barrios R, Heredia JBI, MuyRangel MD, Portillo-Loera JJ

Güçlü BK, Uyanık F, İşcan KM. Effects of dietary oil sources on egg quality, fatty acid composition of eggs and blood lipids in laying quail. South African Journal of Animal Science 2008;38(2):91-100.

Hagger C. Genetic correlations between body weight of cocks and production traits in laying hens, and their possible use in breedings chemes. Poultry Science 1994;73:381-387.

Herstad O, Overland M, Haug A, Skrede A, Thomassen MS, Egaas E. Reproductive performance of broiler breeder hens fed n-3 fatty acid-rich fish oil. Acta Agricultura e Scandinavica Animal Science 2000;50(2):121-128

Hulan HW, Ackman RG, Ratnayake WMN, Proudfoot FG. Omega-3 fatty acid levels and general performance of commercial broilers fed practical levels of red fish meal. Poultry Science 1989;68:153-162.

Jing M, Gakhar N, Gibson RA, House JD. Dietary and ontogenic regulation of fatty acid desaturase and elongase expression in broiler chickens. Prostaglandins Leukotrienes \& Essential Fatty Acids 2013;89(2-3):107113.

Lucotte G. La codorniz: cría y explotación. $2^{\text {nd }}$ ed. Madrid: MundiPrensa;1990.

Manohar GR. Effect of dietary omega-3 fatty acid rich oil sources on fertility and hatchability performance of japanese quail eggs. International Journal of Science, Environment and Technology 2017;6(1):923-926.

Mao JNC, Burnside J, Postel-Vinay MC, Pesek JD, Chambers JR, Cogburn LA. Ontogeny of growth hormone receptor gene expression in tissue of growth-selected strains of broiler chickens. Journal of Endocrinology 1998;156:67-75.

Mennicken L, Ponsuksilli S, Tholen E, Khang NTK, Steier K, Petersen J, et al. Divergent selection for omega 3: omega 6 polyunsaturated fatty acid ratio in quail eggs. Archiv Tierzuchtv 2005;48:527-34.

Mexican, NO. NMX-F-154-1987. Foods. Vegetable or animal oils and fats. Determination of peroxide index Normas Mexicanas. Mexico: Dirección General de Normas; 1987.

Mexican, NO. NOM-062-ZOO-1999. Technical specifications for the production, care and use of laboratory animals: Diario Oficial de la Federación, México DF; 2001.

Minvielle F. The future of Japanese quail for research and production. World's Poultry Science Journal 2004;60:500-507.
Moir KW, Yule WJ, Connor JK. Energy losses in the excreta of poultry: a model for predicting dietary metabolizable energy. Animal Production Science 1980;20(103):151-155.

Morales-Barrera J, González-Alcorta M, Castillo-Domínguez R, PradoRebolledo O, Vázquez J, Hernández-Velasco X, et al. Effect of time and fatty acid composition in eggs of White Leghorn hens supplemented with tuna oil. Food and Nutrition Sciences 2013;4:39-44.

Nadia L, Radwan MH, Abd El-Samad y Sherin AN. Effects of different dietary ratios of linoleic acidto $\alpha$-linolenic acid on productive performance, immunity of laying hens and egg yolk fatty acid composition. Egiptian Poultry Science Journal 2012;32(I):163-188.

Navas JM, Mark AT, Silvia Z, Jesus AR, Niall B, Manuel C. Total lipid in the broodstock diet did not affect fatty acid composition and quality of eggs of sea bass (Dicentrarchus labrax L). Scientia Marina 2001;65(1):11-19.

Neijat M, Suh JM, Neufeld J, House D. Hemp seed products fed to hens effectively increased n-3 polyunsaturated fatty acids in total lipids, triacylglycerol and fhospholipid of eggy olk. Lipids 2016;51:601-614.

Neumann KF. Codornices. Roma Norte: Grupo Editorial Iberoamericana; 2001.

NRC - National Research Council. Nutrient requirements of poultry. $9^{\text {th }}$ ed. Washington: National Academy of Sciences; 1994.

Rodríguez-Michel A, Morales-Barrera E, García-Márquez L, Quezada-Tristán T, Carrillo-Domínguez S, Prado-Rebolledo O. Harina de atún negra en dietas de gallina para incrementar los ácidos eicosapentanoico y docosahexaenoico. Abanico Veterinario 2018;8(3):75-85.

Shamma TA, Samia ZM, Samya E, Ibrahim y El-Aik MA. Effect of omega-3 sources and vitamin supplementation in the turkey toms diet on semen characteristics and fertilizing ability. Journal Animal and Poultry Production Mansoura University 2016;7(3):101-111.

Simopoulos AP. Requirement for n-3 polyunsaturated fatty acids. Poultry Science 2000;79:961-970.

Spector AA. Plasma free fatty acid and lipoproteins as sources of polyunsaturated fatty acid for the brain. Journal of Molecular Neuroscience 2000;16:159-165.

Zanini SF, Torres CAA, Bragagnolo N, Turatti JM, Silva MG, Zanini MS Evaluation of the ratio of omega6: omega3 fatty acids and vitamin $E$ levels in the diet on the reproductive performance of cockerels. Archives of Animal Nutrition 2003;57:429-442. 